\title{
Induction of a cDNA clone from rice encoding a class II small heat shock protein by heat stress, mechanical injury, and salicylic acid
}

\author{
Pi-Fang Linda Chang ${ }^{a, *}$, Tsung-Luo Jinn ${ }^{\mathrm{b}}$, Wen-Kuan Huang ${ }^{\mathrm{a}}$, Yuhsin Chen ${ }^{\mathrm{c}}$, \\ Hsi-Ming Chang ${ }^{\text {a }}$, Cheng-Wei Wang ${ }^{\text {a, }}$ \\ ${ }^{a}$ Department of Plant Pathology, National Chung Hsing University, Taichung 402, Taiwan \\ ${ }^{\mathrm{b}}$ Department of Life Science and Institute of Plant Biology, National Taiwan University, Taipei 106, Taiwan \\ ${ }^{\mathrm{c}}$ Department of Bioscience Technology, Chang Jung Christian University, Tainan 711, Taiwan \\ Received 24 October 2005; received in revised form 21 July 2006; accepted 22 July 2006 \\ Available online 18 August 2006
}

\begin{abstract}
This is the first report of a full-length cDNA clone for a class II small heat shock protein (sHSP) isolated from rice (Oryza sativa L., cv. Tainong No. 67) etiolated seedlings heat shocked at $41{ }^{\circ} \mathrm{C}$ for $2 \mathrm{~h}$. The coding sequence consists of $501 \mathrm{bp}$, and the clone encodes a protein of $18.0 \mathrm{kDa}$ with a predicted $\mathrm{pI}$ value of 5.61. The obtained full-length cDNA clone, designated Oshsp18.0-CII, is almost identical to a putative class II sHSP gene located on rice (cv. Nipponbare) chromosome one and another putative class II sHSP rice gene. Oshsp18.0-CII was induced by mechanical injury and salicylic acid treatment, which is not common in this class of sHSP genes. Only one copy of class II sHSP genes is present in the rice genome, and western blot analysis with anti-PsHSP17.7 (a class II pea sHSP) also showed only one protein of $\sim 18 \mathrm{kDa}$ in the 2D gel of heat-shocked rice proteins. Oshsp18.0-CII is GC-rich and contains a secondary structure in its RNA sequence.
\end{abstract}

(C) 2006 Elsevier Ireland Ltd. All rights reserved.

Keywords: Gene expression; Heat shock (HS); Heat shock protein (HSP); Oryza sativa L.; Wounding

\section{Introduction}

Living organisms greatly alter their patterns of gene expression on exposure to sublethal high temperatures [1]. Elevated temperatures induce the expression of heat-shock proteins (HSPs), and suppress, at least in part, the synthesis of normal cellular proteins. Such response allows organisms to become tolerant to nonpermissive (or lethal) high temperatures. Therefore, thermoprotection by HSPs appears to be important for survival during heat stress [2,3]. The major HSPs studied to date are highly homologous among eukaryotes and, in some cases, among prokaryotes. The evolutionary conservation of genes for HSPs further suggests that the production of HSPs is a basic mechanism for coping with heat shock $[2,3]$.

\footnotetext{
* Corresponding author. Tel.: +886 42284 0780x335/330; fax: +886422860442.

E-mail address: pfchang @nchu.edu.tw (P.-F.L. Chang).

${ }^{1}$ Current address: Graduate Institute of Biotechnology, National Chung Hsing University, Taichung 402, Taiwan.
}

HSPs are divided into low molecular mass proteins of approximately $15-28 \mathrm{kDa}$ (sHSPs) and high molecular mass proteins of more than $30 \mathrm{kDa}$ (HMM HSPs) [2,3]. The HMM HSPs of plants, in contrast to those of animals, represent only a relatively small fraction of the total HSPs. Sequence analysis of sHSPs has revealed a high degree of homology among plant species, although variations in electrophoretic patterns were observed [4]. The sHSPs are classified into six classes: classes I and II are cytosolic proteins, and the others are proteins targeted to chloroplasts, mitochondria, and endomembranes [5,6]. Recently, Scharf et al. [7] identified other sHSP genes outside of the six classes.

The physiological functions of sHSPs in rice have been studied previously [8-13]. Several cDNA clones and genomic clones of rice class I sHSPs have been isolated, and their expression in response to heat stress and other environmental factors has been studied [14-18]. Because of the abundance and complexity of these proteins and because two classes of sHSPs are localized to the cytosol, we were interested in isolating the cDNA clones of class II sHSPs to further analyze the functional differences between these two classes. 
Table 1

PCR primers

\begin{tabular}{|c|c|c|c|}
\hline Primer & Sequence and length (nt) & $\mathrm{F} / \mathrm{R}^{\mathrm{a}}$ & Position $^{b}$ \\
\hline ADVKEL & $5^{\prime}$-GCCGACGT(C/G)AAGGAGCT(C/G)-3' (18) & $\mathrm{F}$ & +163 to +180 \\
\hline KKPKTI (GSP1) & 5'-GATGGTCTTGGGCTTCTT-3' (18) & $\mathrm{R}$ & +466 to +483 \\
\hline ATG & 5'-ATGGAGAGCGCCATGTTCGG-3' (20) & $\mathrm{F}$ & +1 to +20 \\
\hline $3^{\prime} \mathrm{UTR}$ & 5'-CAGATAAGCAGCAGAACATCC-3' (21) & $\mathrm{R}$ & +701 to +721 \\
\hline GSP2 (MGKFMRK) & 5'-TTGCGCATGAACTTGCCCA-3' (19) & $\mathrm{R}$ & +347 to +365 \\
\hline $5^{\prime} \mathrm{UTR}$ & 5'-CCCAGCGCGATCCGAGGTAG-3’ (20) & $\mathrm{F}$ & -63 to -44 \\
\hline
\end{tabular}

${ }^{\mathrm{a}} \mathrm{F}$ and $\mathrm{R}$ denote forward and reverse primer, respectively.

b Position in Oshsp18.0-CII as shown in Fig. 2.

The class II sHSP genes in plants in general are induced by different developmental programs or by microsporogenesis [19-22]. However, AtHsp17.6-II isolated from Arabidopsis [23], PsHsp17.7 isolated from pea [24] and a tomato HSP17.6 gene [25] were inducible by heat stress, and class II sHSP genes of sunflower showed tissue-specific expression in response to water stress [26]. Recently, AtHSP17.6-II and AtHSP17.6A were reported to be induced by wounding [27], which is not common for HSP genes. The level of two class II sHSP transcripts (HSP17.4 and HSP17.6) has also been reported to accumulate in tomato fruit during ripening, chilling storage, and methyl jasmonate (MeJA) and methyl salicylate (MeSA) treatments [25]. In Arabidopsis, Hsp17.6 but not Hspl01 was induced by salicylic acid (SA) [28]. SA also affected Hsp70/ Hsc70 expression in tomato cell suspension cultures [29]. In this report, we describe the isolation of a cDNA clone, Oshsp18.0-CII, encoding a putative rice class II sHSP, and show that it was also inducible by mechanical injury and SA treatment.

\section{Materials and methods}

\subsection{Plant materials and treatments}

Rice (Oryza sativa L. cv. Tainong No. 67) seedlings were germinated in the dark at $28{ }^{\circ} \mathrm{C}$ for 3 days in rolls of moist paper towels as described by Chang et al. [14]. The endospermremoved etiolated seedlings were subjected to $28^{\circ} \mathrm{C}$ (control), $41{ }^{\circ} \mathrm{C}$, wounding (cutting seedlings into $1 \mathrm{~cm}$ fragments) and SA (1 mM) treatment for $1,2,4,8,16$, and 24 h by submerging the seedlings in a buffer solution containing $5 \mathrm{mM}$ potassium phosphate ( $\mathrm{pH} 6.8)$, and $1 \%$ sucrose in a $28^{\circ} \mathrm{C}$ shaking water bath at $30 \mathrm{rpm}$.

\subsection{RNA preparation and reverse transcription- polymerase chain reaction ( $R T-P C R)$}

Total RNA extraction from the treated rice seedlings and poly $(\mathrm{A})^{+}$RNA purification by oligo (dT) cellulose chromatography were performed according to Chang et al. [30] and Lee et al. [16]. The first-strand cDNAs were synthesized from the $\operatorname{poly}(\mathrm{A})^{+} \mathrm{RNAs}$ of 3 -day-old heat-shocked $\left(2 \mathrm{~h}\right.$ at $\left.41{ }^{\circ} \mathrm{C}\right)$ rice seedlings using SuperScript II RNase $\mathrm{H}^{-}$Reverse Transcriptase (Invitrogen). The RT-PCR product was prepared using a PCR kit (Perkin-Elmer Centus) and the first-strand cDNAs as templates [31]. The primers used (listed in Table 1) for PCR were the two 18-nt oligomers ADVKEL and KKPKTI primers. The sequences of these primers were in correspondence with those of the conserved amino acid domains (ADVKEL and KKPKTI) among the coding regions of three maize (Zea mays L.) class II sHSP cDNA clones, $c M H S P 18-1, c M H S P 18-3$, and cMHSP18-9 [19]. The ATG primer (with the sequences corresponding to the first $20 \mathrm{nt}$ started with the ATG start codon) paired with the KKPKTI primer or the $3^{\prime}$ UTR primer (with the sequences corresponding to those of the last $21 \mathrm{nt}$ in the $3^{\prime}$ UTR of the $p O S H S P 2$ as described below) were also used for RT-PCR (see Table 1 for primer sequences). For all PCR programs, the reaction mixture was initially denatured at $94{ }^{\circ} \mathrm{C}$ for 5-7 min, followed by 35 cycles of reaction as listed in Table 2 and ended with $10 \mathrm{~min}$ of extension at $72{ }^{\circ} \mathrm{C}$. The lengths of the PCR bands are listed in Table 2.

\subsection{Cloning and sequence analysis of the RT-PCR products}

The RT-PCR products were gel purified, treated with T4 DNA kinase and cloned into the Sma I site of pGEM-7Zf(+)

Table 2

PCR reactions used in this study and the resulted product sizes

\begin{tabular}{|c|c|c|c|}
\hline Primer pair & 1st denaturation & 35 PCR cycles & Size of PCR product (bp) \\
\hline ADVKEL/KKPKTI & $94^{\circ} \mathrm{C} 5 \mathrm{~min}$ & $94{ }^{\circ} \mathrm{C} 40 \mathrm{~s}, 50{ }^{\circ} \mathrm{C} 40 \mathrm{~s}, 72{ }^{\circ} \mathrm{C} 40 \mathrm{~s}$ & 321 \\
\hline ATG/KKPKTI & $94{ }^{\circ} \mathrm{C} 5 \mathrm{~min}$ & $94{ }^{\circ} \mathrm{C} 40 \mathrm{~s}, 63{ }^{\circ} \mathrm{C} 40 \mathrm{~s}, 72^{\circ} \mathrm{C} 40 \mathrm{~s}$ & $390-436$ \\
\hline ATG/3'UTR & $94^{\circ} \mathrm{C} 5 \mathrm{~min}$ & $94{ }^{\circ} \mathrm{C} 40 \mathrm{~s}, 48^{\circ} \mathrm{C} 40 \mathrm{~s}, 72^{\circ} \mathrm{C} 40 \mathrm{~s}$ & $625-658$ \\
\hline $5^{\prime} \mathrm{RACE}$ & $94{ }^{\circ} \mathrm{C} 7 \mathrm{~min}$ & $94{ }^{\circ} \mathrm{C} 30 \mathrm{~s}, 65^{\circ} \mathrm{C} 30 \mathrm{~s}, 72{ }^{\circ} \mathrm{C} 1 \mathrm{~min}$ & $\begin{array}{l}568 \text { (for SUP/GSP1 primers) } \\
450 \text { (for SUP/GSP2 primers) }\end{array}$ \\
\hline $5^{\prime} \mathrm{UTR} / 3^{\prime} \mathrm{UTR}$ & $94^{\circ} \mathrm{C} 7 \mathrm{~min}$ & $94^{\circ} \mathrm{C} 1 \mathrm{~min}, 48^{\circ} \mathrm{C} 50 \mathrm{~s}, 72^{\circ} \mathrm{C} 1 \mathrm{~min}$ & 784 \\
\hline
\end{tabular}


vector (Promega), or the gel-purified products were cloned directly using the pGEM-T Easy system (Promega). The DNA sequence was determined using the Sequenase Version 2.0 DNA sequencing kit (USB). The 321 bp insert of the RT-PCR clone was used as a probe for library screening and northern blot analysis.

\subsection{Northern blot analysis}

Equal amounts $(10 \mu \mathrm{g})$ of total RNA from the control $\left(28{ }^{\circ} \mathrm{C}\right)$, heat-shocked, wounded and SA-treated rice seedlings were separated on formaldehyde/agarose gels and transferred to Hybond-C extra membranes (Amersham). Filters were subjected to northern hybridization using ${ }^{32} \mathrm{P}$-labeled $321 \mathrm{bp}$ RT-PCR probe according to Chang et al. [14].

\section{5. cDNA library screening}

The rice cDNA libraries were established in a ZAP Express vector (Stratagene) from poly $(\mathrm{A})^{+}$RNAs of 3-day-old heatshocked rice seedlings using the ZAP Express cDNA Gigapack II Gold cloning kit (Stratagene). The libraries $\left(10^{6}\right.$ clones) were screened by hybridization with a ${ }^{32}$ P-labeled 321 bp RT-PCR probe $\left(\sim 8 \times 10^{7} \mathrm{cpm}\right)$ as described above. High stringency screening was performed with a final wash in $0.1 \times \mathrm{SSC} / 0.1 \%$ SDS at $50{ }^{\circ} \mathrm{C}$ for $1 \mathrm{~h}$ [16]. The insert from one positive clone was in vivo excised from the ZAP Express vector and maintained in the $\mathrm{pBK}-\mathrm{CMV}$ phagemid vector (Stratagene) [32]. The sequence of the resulting clone, designated as pOSHSP2, was determined as mentioned above.

\subsection{Rapid amplification of $5^{\prime}$ cDNA ends ( $5^{\prime}$ RACE)}

The 5' RACE was performed using the Smart ${ }^{\mathrm{TM}}$ RACE cDNA Amplification Kit (Clontech). The first-strand cDNAs were synthesized from the poly(A) ${ }^{+}$RNAs of 3-day-old heatshocked rice seedlings with the PowerScript ${ }^{\mathrm{TM}}$ reverse transcriptase (Clontech), the 5' RACE CDS primer and the SMART II A oligonucleotide according to the manufacturer's protocol. The resulting cDNAs underwent PCR with Advantage 2 Polymerase Mix, Universal Primer A Mix, including the Long Universal Primer (LUP) and the Short Universal Primer (SUP) supplied by the kit, and a gene-specific primer 1 (GSP1, the KKPKTI primer mentioned above). A second round of PCR involved amplification with a gene-specific primer 2 (GSP2, see Table 1 for sequence, the antisense sequence corresponding to MGKFMRK), and the SUP. The PCR programs are listed in Table 2. The $5^{\prime}$ RACE products were further subcloned in pGEM-T Easy vector (Promega) and underwent sequencing analysis as described above.

\subsection{Cloning of the full-length Oshsp18.0-CII}

The first-strand cDNAs were synthesized from the poly $(\mathrm{A})^{+}$ RNAs of 3-day-old heat-shocked rice seedlings using the SuperScript in $\mathrm{RNase}^{-}$Reverse Transcriptase (Invitrogen), and then subjected to PCR. The primers used for PCR were the $5^{\prime}$ UTR primer, with the sequence corresponding to the first 20 nt of the $5^{\prime}$ RACE clone, and the $3^{\prime}$ UTR primer described above. The PCR program is listed in Table 2 . The PCR products of about $800 \mathrm{bp}$ were further subcloned in pGEM-T Easy vector (Promega) and underwent sequencing analysis as described above.

\subsection{RNA structure prediction, sequence alignment, and phylogenetic analysis}

The RNA secondary structure of the full-length clone was predicted using the mfold server (Version 3.1) web service (http://www.bioinfo.rpi.edu/applications/mfold/old/rna/) developed by Zuker [33] and Mathews et al. [34]. DNA and protein sequences were aligned using the Biology WorkBench 3.2 (http://workbench.sdsc.edu) CLUSTAL W (1.81) multiple sequence alignments program [35]. For phylogenetic analysis, protein sequences with the out-group LEA (U57639) were aligned using the CLUSTAL X (1.81) multiple sequence alignments program [36]. The relationship between plant classes I and II sHSPs was determined using the PAUP* [37] and neighbor-joining analysis. Protein distance matrices were computed using the Kimura-two parameter. The neighborjoining method was implemented by the bootstrap procedure with 1000 re-samplings of the data.

\subsection{DNA isolation and Southern blot analysis}

Total rice DNA was isolated according to Chang et al. [14]. DNA was digested with different restriction enzymes (New England Biolabs), separated on $1 \%$ agarose gels and transferred to Hybond-C extra membranes (Amersham). Hybridization conditions and the ${ }^{32} \mathrm{P}$-labeled $784 \mathrm{bp}$ Oshsp18.0-CII probe were as described above. The final wash for the filter was in $0.1 \times \mathrm{SSC} / 0.1 \% \mathrm{SDS}$ twice at $70{ }^{\circ} \mathrm{C}$ for $30 \mathrm{~min}$.

\subsection{Protein extraction, PAGEs, and western blot analysis}

Five-day-old rice seedlings without endosperm were heatshocked at $41{ }^{\circ} \mathrm{C}$ for $2 \mathrm{~h}$, then transferred to $28{ }^{\circ} \mathrm{C}$ for 3 -h recovery. Seedlings were harvested and homogenized and the postribosomal supernatant was prepared as described by Jinn et al. [9]. The postribosomal supernatant was fractionated by $70-100 \%$ saturation with ammonium sulfate, and the resulting sHSP-enriched fraction was separated by 2D-PAGE [9]. The protein profile of the sHSP-enriched fraction was observed by silver nitrate staining or was transferred to PVDF membranes (Millipore) for western blot analysis. Equal amounts $(40 \mu \mathrm{g})$ of total protein from the control $\left(28^{\circ} \mathrm{C}\right)$, heat-shocked, wounded, and SA-treated rice seedlings were separated by SDS-PAGE (12.5\% gel) and transferred to PVDF membranes (Millipore) according to Jinn et al. [38]. Protein blots of SDS-PAGE and 2D-PAGE were subjected to western blot analysis with rabbit anti-Oshsp16.9 (a class I sHSP isolated from rice donated by Dr. Chu-Yung Lin) [10] or rabbit anti-PsHSP17.7 (a class II sHSP isolated from pea donated by Dr. Elizabeth Vierling) as the primary antisera, 
followed by HRP-conjugated goat anti-rabbit (Jackson) as the secondary antisera according to the manufacturer's protocol. The antisera were detected by assaying alkaline phosphate activity conjugated to second antisera by color development according to Jinn et al. [38].

\section{Results}

\subsection{Isolation of a rice class II sHSP gene, Oshsp18.0-CII}

By comparing the alignment of deduced amino acid sequences of several class II sHSPs from diverse species reported by Bartling et al. [23], we found two highly conserved domains (ADVKEL and KKPKTI, located near the center and $\mathrm{C}$ terminal of the amino acid sequences, respectively) in four cDNA clones, namely, cMHSP18-1, cMHSP18-3, and cMHSP18-9 of maize [19], and Tahsp17.3 of wheat [39]. Two 18-nt degenerated oligomers, ADVKEL and KKPKTI, were synthesized and used as primers for RT-PCR to obtain a partial cDNA clone encoding a putative class II sHSP of rice. The RT-PCR product consisted of approximately $320 \mathrm{bp}$ (Fig. 1A). Sequence analysis showed that the obtained RTPCR product contained $321 \mathrm{bp}$, encoding 107 amino acid residues (Fig. 2). Northern blot analysis revealed that this RT-PCR product recognized a message of about $800 \mathrm{nt}$ in the RNA samples prepared from heat-shocked rice seedlings (Fig. 1B).

(B)
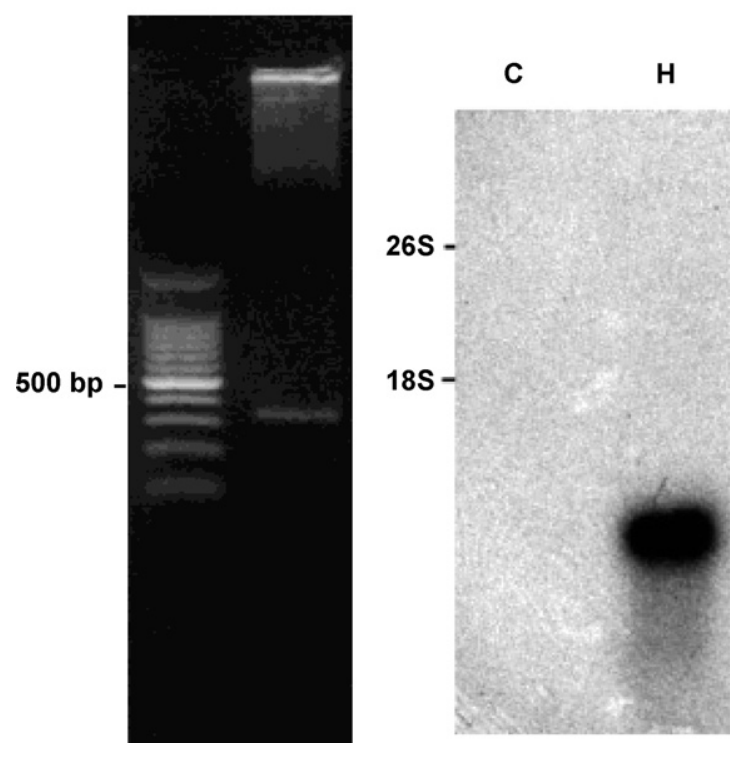

Fig. 1. Agarose gel analysis of RT-PCR products and the induction of the RNA transcript by heat shock using the $321 \mathrm{bp} \mathrm{RT-PCR}$ clone as a probe. (A) A total of $10 \mu \mathrm{l}$ of the RT-PCR products $(100 \mu \mathrm{l} /$ reaction) was separated on a $1 \%$ agarose gel. The gel was stained with ethidium bromide and illuminated on a UV light box to show the DNA bands. The RT-PCR (right lane) produced a band between 300 and $400 \mathrm{bp}$. The $100 \mathrm{bp}$ DNA ladders (Promega) are shown in the left lane. (B) Equal amounts $(10 \mu \mathrm{g})$ of total RNA isolated from control (C; $28{ }^{\circ} \mathrm{C} 2 \mathrm{~h}$ ) and heat shock $\left(\mathrm{H} ; 41^{\circ} \mathrm{C} 2 \mathrm{~h}\right)$ rice seedlings were analyzed on a formaldehyde/agarose gel. The northern hybridization was performed at $42{ }^{\circ} \mathrm{C}$ with ${ }^{32} \mathrm{P}$-labeled RT-PCR clone used as a probe. The locations of $26 \mathrm{~S}$ and $18 \mathrm{~S}$ rRNAs are indicated on the left.
The 321 bp RT-PCR clone was used as a probe to screen the cDNA library made from mRNA of 3-day-old heat-shocked rice seedlings. One putative clone out of $10^{6}$ recombinant plaques screened was isolated, and the insert of the resulted cDNA clone, designated $p O S H S P 2$, consisted of $477 \mathrm{bp}$ with the $3^{\prime}$ UTR of $220 \mathrm{bp}$ before the poly $(\mathrm{A})^{+}$tail, and included $257 \mathrm{bp}$ of coding region. The pOSHSP 2 encodes about 85 amino acids, a sequence identical to that of nucleotides 82 to 321 in the RT-PCR clone (Fig. 2). However, this was not the full length of the cDNA clone. The $5^{\prime}$ region (including the $5^{\prime}$ UTR and coding sequence) of $p O S H S P 2$ was further extended by $5^{\prime}$ RACE. The obtained $5^{\prime}$ RACE clone contained $456 \mathrm{bp}$, the sequence corresponding to $63 \mathrm{bp}$ of the $5^{\prime}$ UTR and $365 \mathrm{bp}$ of the $5^{\prime}$ coding sequence shown in Fig. 2. The oligomers corresponding to the first $20 \mathrm{nt}$ of the $5^{\prime}$ UTR and the last $21 \mathrm{nt}$ of the $3^{\prime}$ UTR (see Table 1 for primer sequences) were used for RT-PCR to obtain a full-length cDNA clone of $784 \mathrm{bp}$, including $63 \mathrm{bp}$ of $5^{\prime} \mathrm{UTR}, 501 \mathrm{bp}$ of coding region, and $220 \mathrm{bp}$ of $3^{\prime}$ UTR.

The coding sequence of the clone consisted of $501 \mathrm{bp}$, suggesting the coding of a protein of $18.0 \mathrm{kDa}$ with a predicted $\mathrm{pI}$ of 5.61. The obtained full-length cDNA clone was hence designated Oshsp18.0-CII (GenBank accession number DQ180746), to be distinguished from the isolated class I sHSP gene Oshsp18.0. The entire Oshsp18.0-CII clone contained $60 \% \mathrm{GC}$, but the first $300 \mathrm{nt}$ in the coding region consisted of $73 \%$ GC. Computer analysis of the RNA secondary structure suggested a strong and complex stem loop structure in the first $300 \mathrm{nt}$ of Oshsp18.0-CII coding sequence (Fig. 3). The predicted structure was low in free energy $(-156)$ and consequently was very stable (Fig. 3).

\subsection{Comparisons of the nucleotides and deduced amino acid sequences of Oshsp18.0-CII with other plant cytosolic sHSP genes}

Comparisons of the nucleotides and deduced amino acid sequences of the Oshsp18.0-CII with other plant sHSP genes are summarized in Table 3. Oshsp18.0-CII shares 82.5-84.2\% DNA identity, 80.2-83.1\% amino acid identity, and 85.9$88.9 \%$ amino acid similarity with three maize clones (cMHSP18-1, cMHSP18-3, and cMHSP18-9) and the wheat clone Tahsp 17.3. The DNA and deduced amino acid sequences of seven published class I sHSP genes from rice (Oshsp16.9A, Oshsp16.9B, Oshsp16.9C, Oshsp17.3, Oshsp17.7, Oshsp17.9, and Oshsp18.0) shared less identity with the sequences of the Oshsp18.0-CII, only 56.1-60.3\% DNA identity and 36.3$41.7 \%$ amino acid identity. Overall, by comparing deduced amino acid sequences, the similarity of Oshsp18.0-CII to other published class II sHSP genes in plants was more than $71 \%$, while that to the published class I sHSP genes in plants was less than $53 \%$ (Table 3). At the DNA level, about $75 \%$ of the $3^{\prime}$ coding sequence of Oshsp18.0-CII was homologous with that of the published class II sHSP genes in plants (data not shown), whereas at the protein level, the $\mathrm{C}$ terminal of the deduced amino acid sequences of the published class II sHSP genes in plants showed the highest homology as compared with the 
1 ATgGAGAGCGCCATGTTCGgGCTGGAGACGCCGCTGATGACGGCGCTGCAGCACCTGCTC

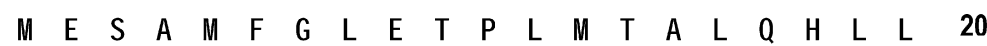

61 GACATCCCCGACGGCGAGGGCGGCGCCGCCGGGAAGCAGGGCGCGACCGGTGGCCCGACG

$\begin{array}{lllllllllllllllllllll}D & \text { I } & P & D & G & E & G & G & A & A & G & K & Q & G & A & T & G & G & P & T & 40\end{array}$

121 CGTGCGTACGTGCGCGACGCCCGCGCCATGGCGgCGACCCCCGCCGACGTGAAGGATCTG

$\begin{array}{lllllllllllllllllllll}R & A & Y & V & R & D & A & R & A & M & A & A & T & P & A & D & V & K & D & L & 60\end{array}$

181 CCCGGGGCGTACGCGTTCGTGGTGGACATGCCTGGGCTCAAGTCCTCCGACATCAAGGTG

$\begin{array}{lllllllllllllllllllll}P & G & A & Y & A & F & V & V & D & M & P & G & L & K & S & S & D & I & K & V & 80\end{array}$

241 CAGGTGGAGGAGGAGAGGCTGCTGGTGATCAGCGGGGAGCGGCGGCGCGGCGGCGGGGAG

$\begin{array}{lllllllllllllllllllll}Q & V & E & E & E & R & L & L & V & I & S & G & E & R & R & R & G & G & G & E & 100\end{array}$

301 GAGGAGAAGGAGGAGTCGTGCAAGTACCTGCGGATGGAGCGGCGGATGGGCAAGTTCATG

$\begin{array}{lllllllllllllllllllll}E & E & K & E & E & S & C & K & Y & L & R & M & E & R & R & M & G & K & F & M & 120\end{array}$

361 CGCAAGTTCGTGCTCCCCGACAACGCCGACGTCGACAAGATCTCCGCCGTGTGCCAGGAC

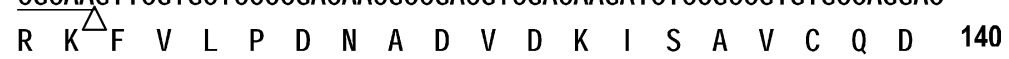

421 GGCGTGCTCACCGTCACCGTCGAGAAGCTCCCGCCGCCGGAGCCCAAGAAGCCCAAGACC

$\begin{array}{lllllllllllllllllllll}G & V & L & T & V & T & V & E & K & L & P & P & P & E & P & K & K & P & K & T & 160\end{array}$

481 ATCGAGGTCAAGGTCGCGTGAtgagattccgcatctctctgcatctgcgtcgctgcgtgg

I E $V$ K V A *

166

541 atcaaagaatcgaagcttgagttgagtgagttgtgactagtagtatgagtagagtgttca

601 tctttatcgtttgctacgtgagaatgtgaggacatggtggtctgtatgccgtatgcgatg

661 tgatgatgatggatggtttgatgtttggtaatggaaatggggatgttctgctgcttatct

$721 \mathrm{~g}$

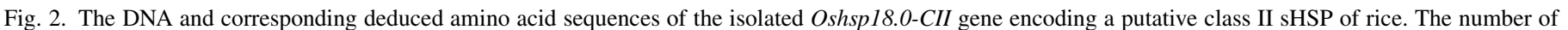

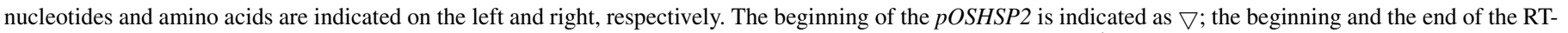

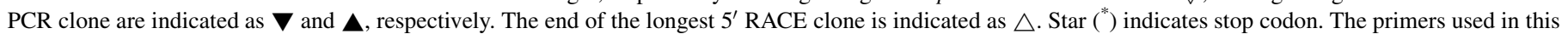
study as indicated in Section 2 are underlined. The GenBank accession number for Oshsp18.0-CII is DQ180746.

$\mathrm{N}$ terminal (Fig. 4A). The $\mathrm{C}$ terminal of the published class I sHSP genes in rice and Oshsp18.0-CII, however, also showed some sequence similarity as indicated in Fig. 4A. When the deduced amino acid sequences of the published classes I and II sHSP genes in plants were compared with those of Oshsp18.0-
CII (Fig. 4A), the C-terminal sequences all showed some level of similarity. According to the dendrogram drawn from the similarity of deduced amino acid sequences (Fig. 4B), Oshsp18.0-CII was grouped with the class II sHSP genes and separated from the other class I sHSP genes.

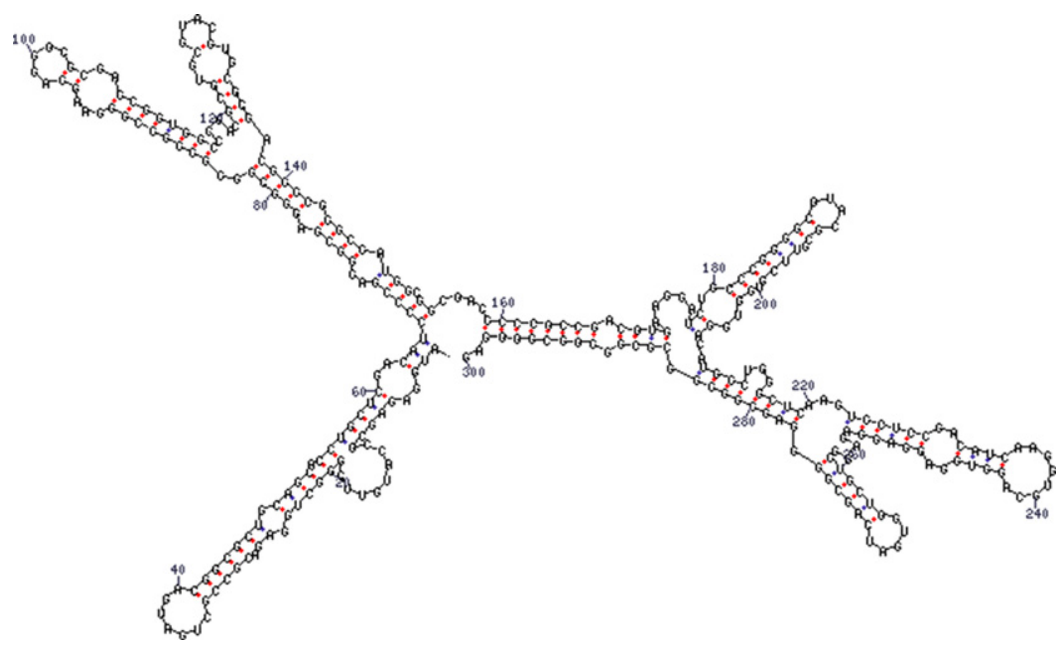

Fig. 3. The secondary structure of the first $300 \mathrm{nt}$ of the coding sequence of Oshsp18.0-CII mRNA predicted by mfold server. Only one secondary structure predicted, with the lowest free energy, is shown. The free energy $(\triangle G)$ is -150.52 (initially -155.4 ). 
Table 3

Relationships of nucleotide sequences and deduced amino acid sequences between the coding region of $O$ shsp18.0-CII and other plant sHSP genes

\begin{tabular}{|c|c|c|c|c|}
\hline \multirow[t]{2}{*}{ Species } & \multirow[t]{2}{*}{ Gene (accession number) } & \multicolumn{3}{|c|}{ Identity or similarity (\%) } \\
\hline & & DNA & $\mathrm{AA}-\mathrm{I}^{\mathrm{a}}$ & $\mathrm{AA}-\mathrm{S}^{\mathrm{b}}$ \\
\hline \multicolumn{5}{|l|}{ Class II } \\
\hline Zea mays & cMHSP18.1 (X54075) & 84.2 & 82.1 & 88.2 \\
\hline Triticum aestivum & Tahsp17.3 (X58279) & 83.7 & 80.2 & 85.9 \\
\hline Zea mays & cMHSP18.9 (S59777) & 83.4 & 82.4 & 88.9 \\
\hline Zea mays & cMHSP18.3 (X54076) & 82.5 & 83.1 & 87.5 \\
\hline Pharbitis nil & sHSP-2 (M99430) & 67.2 & 61.7 & 72.2 \\
\hline Pharbitis nil & sHSP-1 (M99429) & 66.2 & 60.0 & 71.6 \\
\hline Helianehus annuus & HaHSP17.9 (Z29554) & 65.6 & 67.0 & 75.3 \\
\hline Glycine $\max$ & GmHSP17.9-D (X07159) & 65.0 & 66.6 & 75.4 \\
\hline Arabidopsis thaliana & AtHSP17.6-II (X63443) & 61.9 & 63.2 & 74.1 \\
\hline Pisum sativum & PsHSP17.7 (M33901) & 61.6 & 65.7 & 75.6 \\
\hline \multicolumn{5}{|l|}{ Class I } \\
\hline Oryza sativa & Oshsp16.9B (M80939) & 60.3 & 38.5 & 50.0 \\
\hline Oryza sativa & Oshsp16.9A (X60820) & 59.8 & 38.5 & 50.0 \\
\hline Oryza sativa & Oshsp16.9C (U81385) & 59.1 & 39.1 & 49.6 \\
\hline Oryza sativa & Oshsp17.7 (U83671) & 58.5 & 41.7 & 52.6 \\
\hline Oryza sativa & Oshsp18.0 (U83670) & 57.2 & 36.3 & 46.1 \\
\hline Triticum aestivum & $C 5-8(\mathrm{X} 13431)$ & 57.0 & 36.0 & 48.3 \\
\hline Oryza sativa & Oshsp17.3 (M80186) & 56.3 & 39.7 & 52.1 \\
\hline Oryza sativa & Oshsp17.9 (AY034057) & 56.1 & 39.3 & 50.9 \\
\hline Arabidopsis thaliana & AtHSP17.6 (X16076) & 48.2 & 37.0 & 48.7 \\
\hline Glycine max & GmHSP17.5-E (M11395) & 48.1 & 39.7 & 51.7 \\
\hline Pisum sativum & PsHSP17.9 (M33900) & 47.8 & 37.0 & 50.0 \\
\hline
\end{tabular}

${ }^{\text {a }}$ Amino acid identity.

b Amino acid similarity.

\subsection{Induction of Oshsp18.0-CII by heat shock, wounding and $S A$ treatment}

Oshsp18.0-CII was inducible by heat shock at $41{ }^{\circ} \mathrm{C}$ during $24 \mathrm{~h}$. The transcript level was highest at $1 \mathrm{~h}$ after heat shock, remained high at $2 \mathrm{~h}$, and then decreased rapidly with time. After prolonged heat stress of 16-24 h, however, Oshsp18.0CII was still induced but to a much lower level (Fig. 5A). The Oshsp18.0-CII protein started to accumulate at $8 \mathrm{~h}$ and gradually increased in level during $24 \mathrm{~h}$ (Fig. 5B). Oshsp18.0-CII also was inducible by mechanical injury and $\mathrm{SA}$, but to a much lower level as compared with heat shock (Figs. 5A and 6). However, mechanical injury and SA did not induce Oshsp18.0-CII protein accumulation (Fig. 5B).

\subsection{Determination of copy numbers of class II sHSP gene in rice}

According to Southern blot analysis, the 784 bp Oshsp18.0CII recognized only one to two major bands of total rice DNA digested with different restriction enzymes (Fig. 7). This result indicated that one copy or low copy numbers of class II sHSP gene was present in the rice genome of cv. Tainong No. 67, a japonica cultivar. Western blot analysis of the sHSP-enriched fraction (Fig. 8A) with anti-PsHSP17.7 also showed only one protein spot of $\sim 18 \mathrm{kDa}$ with acidic pI (Fig. $8 \mathrm{C}$ and D), even though more than four protein spots of $15-18 \mathrm{kDa}$ with acidic to basic $\mathrm{pI}$ were recognized by anti-Oshsp16.9 (Fig. 8B and D).

\section{Discussion}

An RT-PCR product of about 320 bp (Fig. 1A) was obtained from the rice heat-shocked mRNA using the primer pair designed from the conserved regions of four cDNA clones of two monocots. This RT-PCR clone hybridized with a message of about $800 \mathrm{nt}$ in the RNA samples prepared from heatshocked rice seedlings (Fig. 1B), but did not cross-hybridize with Oshsp16.9A (Chang, unpublished data), a rice gene encoding a class I sHSP [18]. These results suggested that the obtained fragment represented a partial cDNA clone of a heatinducible transcript different from the class I sHSPs of rice. Sequence of the obtained full-length cDNA clone (Fig. 2), Oshsp18.0-CII, shared $100 \%$ identity with a putative class II sHSP gene (accession number AP002484) located on rice (cv. Nipponbare) chromosome one [40]. The Oshsp18.0-CII coding region also differed only in a 3-nt (AAG) insertion in nucleotides -16 to -14 of the $5^{\prime}$ UTR and a 1 -nt difference (C versus A) in nucleotide 387 of that of another putative class II sHSP gene (accession number AK071240, cv. Nipponbare) [41], with no difference in deduced amino acid sequences.

When comparing the nucleotides and deduced amino acid sequences with those of other plant sHSP genes (Table 3), Oshsp18.0-CII shared more than $80 \%$ identity with four monocot clones, but less than $61 \%$ identity with the rice class I sHSP genes. From the dendrogram shown in Fig. 4B, it is clear that Oshsp18.0-CII is a class II sHSP gene. The $3^{\prime}$ coding sequence (Chang, unpublished data) and $\mathrm{C}$ terminal but not $\mathrm{N}$ 


\begin{tabular}{|c|c|}
\hline 0shsp18. 0-CII & MESA---------MFGLETPLMTALQHLLDIPDGEGGAAGKQ-GATGGP 39 \\
\hline cMHSP18. 9 & ---MFGLETPRVAALHHLLDVPDGDK---------AGGGA 32 \\
\hline cMHSP18. 1 & MDAV----------MFGLETPLMAALQHLLDVPDGDAGAGGDNKTGSGGSA 41 \\
\hline cMHSP18. 3 & MDGR---------MFGLETPLMVALQHLLDVPDGDAGAGGDK-AGGGGP 39 \\
\hline Tahsp17. 3 & MAGM---------VFGLDAPMMAALQHLLDIPDGEAEPPPEK-----QGP 36 \\
\hline AtHSP17. 6-II & MDLG------------RF-PI ISILEDMLEVPEDHNNEKTRN----N-P 31 \\
\hline HaHSP17. 9 & ---SLMGFDPLLRNLHYILEATDDNTTGNKSN----NSGP 37 \\
\hline PsHSP17. 7 & MDLD--------------SPLFNTLHHIMDLTDD-TTEKN------LNAP 29 \\
\hline GmHSP17. 9-D & MDFR---------VMGLESPLFHTLQHMMDMSED-GAGDNKT----HNAP 36 \\
\hline sHSP-1 & MDLR---------LMGFDHPLFH----HIMDYAGD-DKSSN-------SSAP 31 \\
\hline sHSP-2 & MDLRNFGLS----NFGLEPQLLSTIQDMLDFADDHDRAGRAP----PEQP 42 \\
\hline PsHSP17. 9 & --I IPRVFGTGRRTNAFDPFSLDLW-DPFQNFQLAR-SATG---------- 37 \\
\hline GmHSP17. 5-E & MSLIPGFFG-GRRSNVFDPFSLDMW-DPFKDFHVPT-SS---- \\
\hline AtHSP17. 6 & MSLIPSIFG-GRRTNVFDPFSLDVF-DPFEGFLTPSGLANA---------- 39 \\
\hline 0shsp16.9A & MSLV--------RRSNVFDPFSLDLW-DPFDSVFRSVVPATS---------- 33 \\
\hline 0shsp16.9B & MSLV--------RRSNVFDPFSLDLW-DPFDSVFRSVVPATS---------- 3 \\
\hline 0 shsp16.9C & MSLV-------RRSNVFDPFA-DFW-DPFDGVLRSLVPATS--------- 32 \\
\hline C5-8 & MSIV--------RRSNVFDPFA-DLWADPFD-TFRSIVPAISG \\
\hline Oshsp17.9 & MSLI-------RRSNVFDPFSLDLW-DPFDGFPFGSGGSSS-GSIFPSF 40 \\
\hline 0shsp18. 0 & MSLI-------RRSNVFDPFSLDLW-DPFDGFPFGSGSRSS-GTIFPSF 40 \\
\hline 0shsp17. 3 & MSMI--------RRSNVFDPFSLDLW-DPFDGFPFGSG---S--GSLFP-- 35 \\
\hline 0shsp17. 7 & MSLI--------RRGNAFDPFSLDLW-DPVDGFPFGSGGSSSSSGSLFP-- 40 \\
\hline
\end{tabular}

0shsp18. 0-CI I cMHSP18. 9 cMHSP18. 1 cMHSP18. 3 Tahsp17. 3 AtHSP17. 6-II HaHSP17. 9 PsHSP17. 7 GmHSP17. 9-D SHSP-1 sHSP-2 PsHSP17. 9 GmHSP17. 5-E AtHSP17. 6 0shsp16.9A 0shsp16. 9B 0shsp16. 9C C5-8 0shsp17.9 0shsp18. 0 0shsp17. 3 0shsp17. 7
TRAYVRDARAMAATPADVKDLPGAYAFVVDMPGLKSSDIKVQVEEERLLV 89 TRTYVRDARAMAATPADVKELAGAYAFVVDMPGLSTGDIRVQVEDERVLV 82 TRTYVRDARAMAATPADVKELPGAYAFVVDMPGLGTGDIRVQVEDERVLV 91 TRTYVADARAMAVTPADVKELPGAYAFVVDMPGLGTGDIKVQVEDERVLV 89 TRAYVRDARAMAATPADVKELPGAYAFVVDMPGLGSGDIKVQVEDERVLV 86 SRVYMRDAKAMAATPADVIEHPNAYAFVVDMPGIKGDEIKVQVENDNVLV 81 SRAYVRDARAMAATPADVKECPNSYVF IVDMPGLKSGDIKVQVERDNVLV 87 TRTYVRDAKAMAATPADVKEHPNSYVFMVDMPGVKSGDIKVQVEDENVLL 79 TWSYVRDAKAMAATPADVKEYPNSYVFEIDMPGLKSGDIKVQVEDDNLLL 86 SRTFMLDAKAMAATPADVKEYPNSYVF I IDMPGLKSGDIKVQVDGDNVLS 81 IRAYVRDAKAMAATPADVKEYPNSYVF IADMPGVKAAEIKVQVEDDNVLV 92 ---TTNETAAFANAHIDWKETPEAHVFKADLPGVKKEEVKVEIEEDRVLK 84 ---VSAENSAFVSTRVDWKETPEAHVFKADIPGLKKEEVKVQIEDDRVLQ 83 ---PAMDVAAFTNAKVDWRETPEAHVFKADLPGLRKEEVKVEVEDGNILQ 86 ----DNDTAAFANARIDWKETPESHVFKADLPGVKKEEVKVEVEEGNVLV 79 ----DNDTAAFANARIDWKETPESHVFKADLPGVKKEEVKVEVEEGNVLV 79 ----DRDTAAFANARVDWKETPESHVFKADLPGVKKEEVKVEVEEGNVLV 78 ---GSSETAAFANARVDWKETPEAHVFKVDLPGVKKEEVKVEVEDGNVLV 80 PRGASSETAAFAGARIDWKETPEAHVFKADVPGLKKEEVKVEVDDGNILQ 90 PRGTSSETAAFAGARIDWKETPE-HVFKADVPGLKKEEVKVEVEDGNVLQ 90 -R-ANSDAAAFAGARIDWKETPEAHVFKADVPGLKKEEVKVEVEDGNVSR 83 -R-ANSDAAAFAGARIDWKETPEVHVFKADVPGLKKEEVKVEVDDGNILQ 88

$$
\text { : *: : }: * \text { : . : ** *:**: :::*::: .: }
$$

Fig. 4. Deduced amino acid sequence alignment of the Oshsp18.0-CII with published class I and class II sHSP genes in plants and the phylogenetic relationships. (A) The number of amino acids is indicated on the right. The class I sHSP genes compared are GmHSP17.5-E, PsHSP17.9, Oshsp16.9A, Oshsp16.9B, Oshsp16.9C, C5-8, Oshsp17.3, Oshsp18.0, Oshsp17.7, Oshsp17.9, and AtHSP17.6, and class II genes are HaHSP17.9, sHSP-1, GmHSP17.9-D, PsHSP17.7, AtHSP17.6-II, sHSP-2, cMHSP18.1, cMHSP18.3, cMHSP18.9, Tahsp17.3, and Oshsp18.0-CII as in Table 3. Protein sequences were aligned by use of Biology WorkBench 3.2 CLUSTAL W (1.81) multiple sequence alignments program. Consensus keys shown are: ‘*' for single, fully conserved residue; ':' for conservation of strong groups; '.'for conservation of weak groups; '-' for no consensus. (B) Phylogenetic relationships of the plant class II sHSP genes based on sequence alignments of the mature encoded proteins. Sequences were aligned by use of CLUSTAL X (1.81) multiple sequence alignments program. The analysis was based on alignment of 22 unique sHSP amino acid sequences, with the rice LEA protein sequence (U57639) used as an out-group for comparison. The evolutionary tree was constructed by the Neighbor-Joining method and drawn by the Tree View program. The bootstrap values are shown on each branch (\% of 1000 re-sampled data set); only values greater than $60 \%$ are shown. 
terminal of the deduced amino acid sequence (Fig. 4A) of the Oshsp18.0-CII showed high identity with those of the published plant class II HSP genes. The $\mathrm{C}$ terminal but not $\mathrm{N}$ terminal also showed some degree of homology with those of published rice and other plant class I sHSP genes (Fig. 4A). Sequence conservation of the $\mathrm{C}$-terminal amino acid sequences appeared to exist in most of the sHSP genes in plants [6].

Oshsp18.0-CII was induced by heat shock, mechanical injury and SA (Figs. 5A and 6). Recently, AtHSP17.6-II and AtHSP17.6A were found to be induced by wounding [27]. The level of two class II sHSP transcripts (HSP17.4 and HSP17.6) increased in tomato fruit during ripening, chilling storage, and MeJA and MeSA treatments [25]. SA has been reported to induce Hsp17.6 but not HsplO1 in Arabidopsis [28], and influence Hsp70/Hsc70 expression in tomato cell suspension cultures [29]. The induction level of our putative class II sHSP gene Oshsp18.0-CII by mechanical injury and SA treatment was much less than that by heat shock. However, only heat shock but not mechanical injury or SA treatment induced Oshsp18.0-CII protein accumulation (Fig. 5B). Our results 0shsp18. 0-CI I cMHSP18. 9 cMHSP18. 1 cMHSP18. 3

Tahsp17.3 AtHSP17. 6-II HaHSP17. 9 PsHSP17. 7 GmHSP17. 9-D sHSP-1 sHSP-2 PsHSP17. 9 GmHSP17. 5-E AtHSP17. 6 0shsp16.9A 0shsp16.9B 0shsp16. 9C C5-8 Oshsp17.9 0shsp18. 0 0shsp17. 3 0shsp17. 7

0shsp18. 0-CI I cMHSP18. 9 cMHSP18. 1 cMHSP18. 3 Tahsp17. 3 AtHSP17. 6-II HaHSP17. 9 PsHSP17. 7 GmHSP17. 9-D SHSP-1 SHSP-2 PsHSP17. 9 GmHSP17. 5-E AtHSP17. 6 0shsp16.9A Oshsp16. 9B 0shsp16. 9C C5-8 0shsp17. 9 0shsp18. 0 Oshsp17. 3 0shsp17. 7

(A)

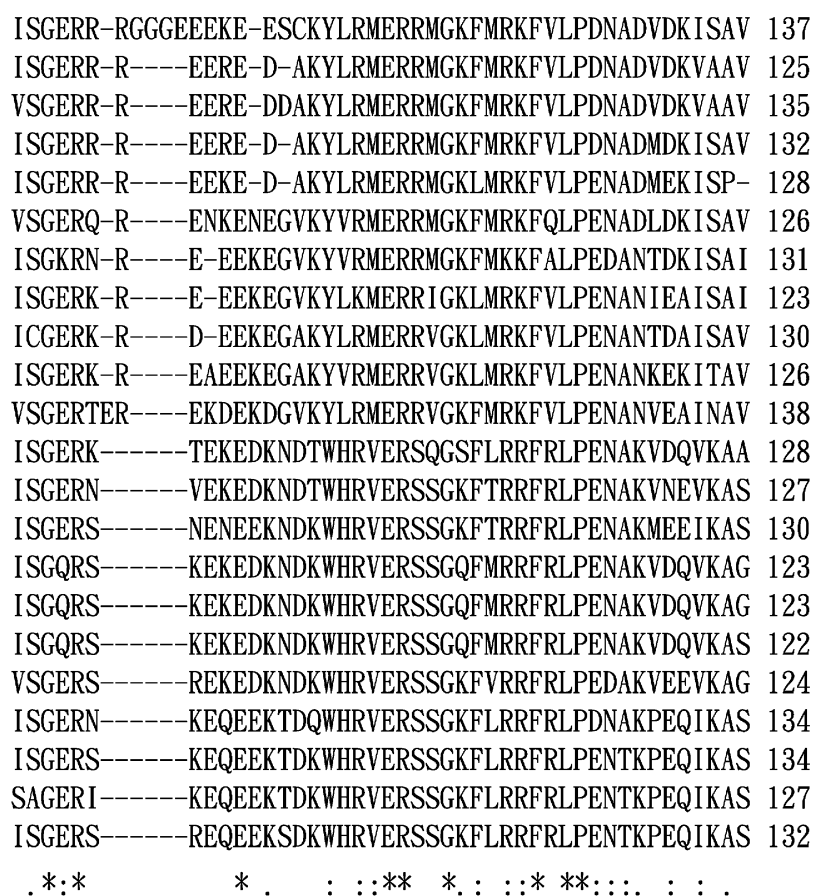

.*:* *. : : :** *.: : :***::: : : .

CQDGVLTVTVEKLPPPEPKKPKTIEVKVA- 166 CRDGVLTVTVEKLPPPEPKKPKTIEIKVA- 154

CRDGVLTVTVEKLPPPEPKKPKTIEVKVA- 164

CRDGVLTVTVEKLPPPEPKKPKTIEVKVA- 161

CRDGVLTVTVDKLPPPEPKKPKTIQVQVA- 157

CHDGVLKVTVQKLPPPEPKKPKTIQVQVA- 155

CQDGVLTVTVEKLPPPEPKKPKTIQVQVA- 160

SQDGVLTVTVNKLPPPEPKKPKTIQVKVA- 152

CQDGVLSVTVQKLPPPEPKKPRTIQVKVA- 159

CQDGVLTVTVENVPPPEPKKPRTIEVKIG- 155

YQDGVLQVTVEKLPPPEPKKPKTVEVKVA- 167

MENGVLTVTVPKE---EVKKPEAKPIQITG 155

MENGVLTVTVPKE---EVKKPDVKAIEISG 154

MENGVLSVTVPKV---PEKKPEVKSIDISG 157

LENGVLTVTVPKA---EVKKPEVKAIEISG 150

MENGVLTVTVPKA---EVKKPEVKAIEISG 150

MENGVLTVTVPKA---EVNKPEVKAIEISG 149

LENGVLTVTVPKA---EVKKPEVKAIEISG 151

MENGVLTVTVPKE---EAKKPDVKSIQISG 161

MENGVLTVTVPKE---EPKKPDVKSIQVTG 161

MENGVLTVTVPKE---EPKKPDVKSIQITG 154

MENGVLTVTVPKE---EPKKPDVKSIQISG 159

.:******: :**. : :

Fig. 4. (Continued) 


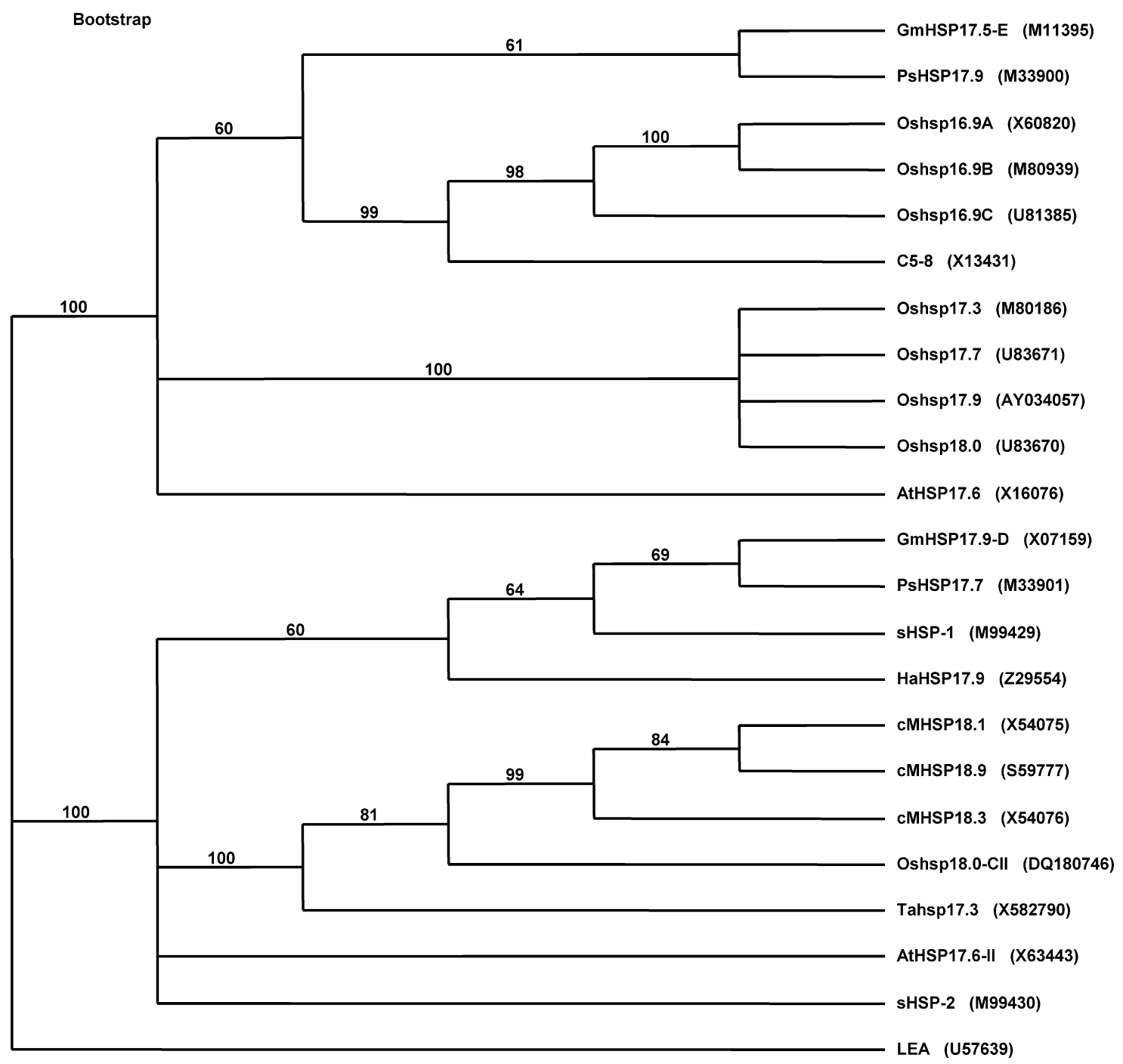

(B)

Fig. 4. (Continued).

suggest some posttranscriptional regulation of class II sHSP genes under stresses other than heat shock. It is conceivable that the protein level induced by SA or wounding was too low to be detected by western blot analysis.
Although induction of plant HSPs is generally considered to be an abiotic stress response [42], it has also been shown to be involved in the biotic stress response. The HSP70 gene was known to be induced by infection with a cyst nematode in

(A)

$1 \mathrm{hr} \quad 2 \mathrm{hr} \quad 4 \mathrm{hr}$

$8 \mathrm{hr}$

$16 \mathrm{hr}$

$24 \mathrm{hr}$

\begin{tabular}{llllllllllllllllllllllll}
\hline 28 & 41 & W & SA & 28 & 41 & W & SA & 28 & 41 & W & SA & 28 & 41 & W & SA & 28 & 41 & W & SA & 28 & 41 & W & SA
\end{tabular}

Oshsp18.0-CII

rRNA

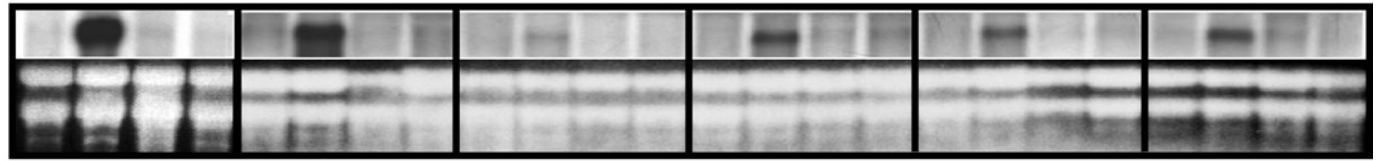

(B)

Oshsp18.0-CII

Fig. 5. Induction of the Oshsp18.0-CII mRNA and accumulation of the Oshsp1 8.0-CII protein in 3-day-old etiolated rice seedlings treated with $28{ }^{\circ} \mathrm{C}(\mathrm{C}), 41{ }^{\circ} \mathrm{C}(\mathrm{H})$, wounding (W; cut seedlings), and salicylic acid (SA; $1 \mathrm{mM}$ ) for 1, 2, 4, 8, 16, and $24 \mathrm{~h}$. (A) Equal amounts (10 $\mu \mathrm{g}$ ) of total RNA were analyzed on a formaldehyde/ agarose gel. Northern hybridization was performed at $42{ }^{\circ} \mathrm{C}$ with ${ }^{32} \mathrm{P}$-labeled $O$ shsp 18.0-CII used as a probe. rRNAs are shown for RNA loading reference. (B) Equal amounts $(40 \mu \mathrm{g})$ of total protein were separated by SDS-PAGE (12.5\% gel) and subjected to western analysis using rabbit anti-PsHSP17.7 (a class II sHSP isolated in pea) as the primary antisera. 
(A)

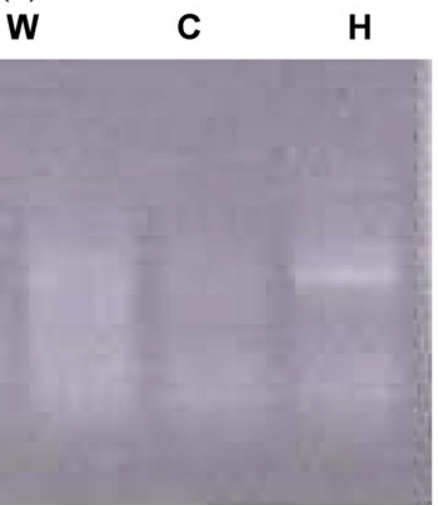

(B)

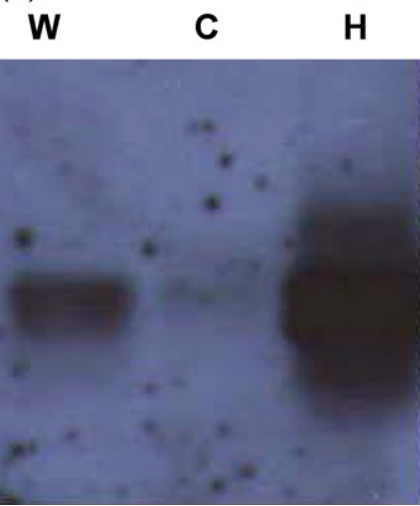

Fig. 6. RT-PCR of rice RNA isolated from control, heat-shocked, or wounded rice seedlings with PCR primers specific to class II sHSP genes. (A) A total of $10 \mu \mathrm{l}$ of the RT-PCR products $(25 \mu \mathrm{l} /$ reaction) from RNA isolated from rice seedlings treated with $28{ }^{\circ} \mathrm{C}(\mathrm{C}), 41^{\circ} \mathrm{C}(\mathrm{H})$, and wounding (W) for $1 \mathrm{~h}$ were separated on a $1 \%$ agarose gel. The gel was stained with ethidium bromide and illuminated on a UV light box to show the DNA bands. RT-PCR produced a band between 300 and $400 \mathrm{bp}$. (B) The corresponding Southern hybridization was performed at $42{ }^{\circ} \mathrm{C}$ with ${ }^{32} \mathrm{P}$-labeled RT-PCR clone used as a probe.

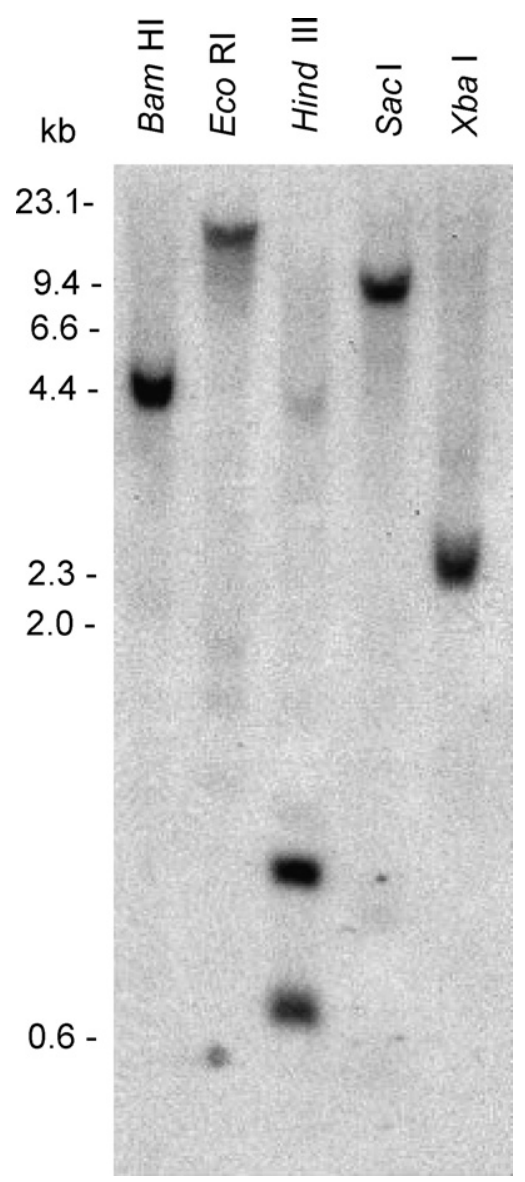

Fig. 7. Southern blot analysis of rice genomic DNA probed with Oshsp18.0CII. Equal amounts $(15 \mu \mathrm{g})$ of rice genomic DNA were digested with Bam HI, Eco RI, Hind III, Sac I, and $\mathrm{Xba}$ I restriction enzymes at $37^{\circ} \mathrm{C}$ for overnight and analyzed on a $0.7 \%$ agarose gel. Southern hybridization was performed at $42{ }^{\circ} \mathrm{C}$ with ${ }^{32} \mathrm{P}$-labeled Oshsp18.0-CII used as a probe. The locations of DNA size markers are indicated on the left.

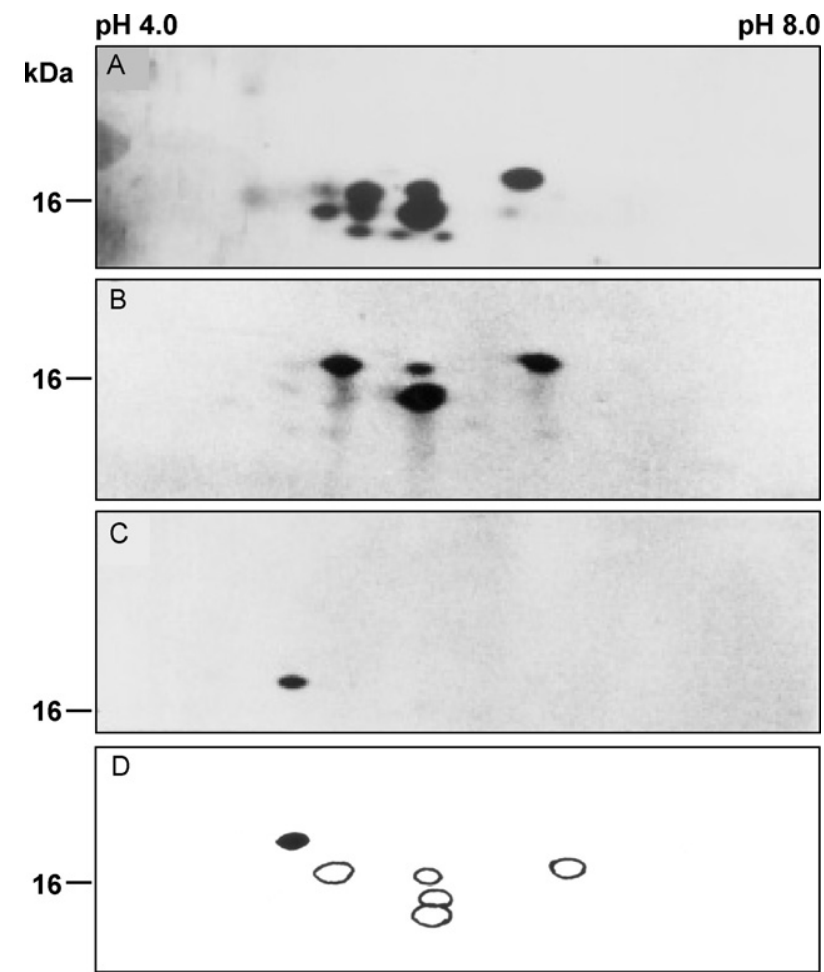

Fig. 8. Identification of class II sHSPs in rice. The sHSP-enriched fraction by 70-100\% ammonia sulfate fractionation was separated by 2D-PAGE. Panel A, the total protein profile in this fraction shown by silver nitrate staining. Panel B, antisera against class I sHSPs in rice were used for western blotting; Panel C, antisera against class II sHSPs in pea were used for western blotting. The immunoreactions were detected by assaying alkaline phosphate activity conjugated to second antisera by color development. Panel D, diagrammatic representation of the total 15-18 kDa sHSPs where the proteins cross-reacted to antisera against class I (open circle) and class II (black circle) sHSPs detected in rice. Sizes of the molecular mass markers are indicated at the left.

soybean [43]. In Arabidopsis, AtHSP90.1 and cytosolic HSP90 have been reported to be required for disease resistance [44,45]. Moreover, HSP70 and HSP90 have also been shown to be essential for hypersensitive response and nonhost resistance in Nicotiana benthamiana [46]. Whether Oshsp18.0-CII is involved in crop protection against biotic stresses remains to be determined.

Computer analysis of RNA secondary structure revealed the existence of strong and complex stem loop structures in the first $300 \mathrm{nt}$ (73\% GC) of the coding region of Oshsp18.0-CII (Fig. 3) and suggested its possible folding into a stem-loop structure during RT or even PCR. This may be the reason for our failure to obtain a full-length clone by heat-shock cDNA library screening. When we later designed a specific ATG primer, which contained the predicted start codon of the putative class II sHSP gene of rice cultivar Nipponbare (AK071240) to pair with the KKPKPI or $3^{\prime}$ UTR antisense primer for PCR analysis of the heat-shocked cDNA, the resulted RT-PCR products had sizes ranging from 390 to $436 \mathrm{bp}$ or 625 to $658 \mathrm{bp}$ (Table 2). The $5^{\prime}$ end sequences of the RT-PCR products, generated by these two primer pairs, showed various lengths (47-96 nt) of deletion regions spanning from the DNA sequence corresponding to nucleotides $65-190$ of the coding region in the Oshsp18.0-CII sequence (Chang, unpublished data). The remaining sequences in the entire $501 \mathrm{bp}$ 
coding region and the $3^{\prime}$ UTR were the same. The isolated $18 \mathrm{kDa}$ HSP genes in maize also revealed small deletions scattered in similar regions of different cDNA clones (cMHSP18-1, cMHSP18-3, and cMHSP18-9) [19].

Frappier et al. [47] demonstrated that in vitro transcription of the mRNA from the cDNA clone $c M H S P 18-9$ is responsible for the synthesis of three members of the sHSP family in maize and suggested that $c M H S P 18-3$ and $c M H S P 18-1$ may be responsible for the synthesis of five additional members of this family. They further suggested that in maize a single gene might produce a number of different proteins [47]. Although we obtained several deletion clones some of which even encoded shorter peptides with the same open reading frame as Oshsp18.0-CII, our Oshsp18.0-CII has only one protein product (Fig. 8). We, therefore, speculate that the variation in deletions in our RT-PCR products for the putative class II sHSP gene was due to the strong secondary structure of the class II sHSP mRNA at that region, which is not easy to be dissociated at $42{ }^{\circ} \mathrm{C}$ by regular RT methods. When we later used SuperScript III RNase $\mathrm{H}^{-}$Reverse Transcriptase and $65^{\circ} \mathrm{C}$ for RT, no such deletion was found in the obtained clones (Chang, unpublished data). Moreover, when the genomic DNA was used as PCR templates, the resulting clones also contained no deletion. Our results showed that for GC-rich genes or RNA sequences containing a significant secondary structure, the cDNA clones obtained by RT-PCR may contain some deletions.

Prior to our report, there was only one putative rice class II sHSP gene (AK071240) [41] deposited in GenBank. Results from the Rice Genome Project also revealed one putative HSP gene (AP002484) in a PAC clone (P0489A01) located on chromosome one [40]. The coding sequences of these two genes and our Oshsp18.0-CII are almost identical. This is consistent with the evidence obtained in this study, which suggested that there is only one copy of class II sHSP gene in rice (Fig. 7).

\section{Acknowledgements}

This research was supported in part by grants NSC88-231 1B-005-042, NSC89-2311-B-005-022 and NSC89-2313-B-005159 from the National Science Council, Taiwan, and grant CC95313-D from National Chung Hsing University, Taichung, Taiwan. The authors are grateful to Dr. Chu-Yung Lin for his valuable suggestions, donation of anti-Oshsp16.9, and critical reading of the manuscript. We also thank Dr. Elizabeth Vierling for donating anti-PsHSP17.7; Dr. Chang-Sheng Wang for providing the rice seeds; Dr. Yue-Ie Caroline Hsing for critical reading of the manuscript; Dr. Wen-Hsin Chung for assistance with sequence alignment for generating the phylogenetic trees. The technical assistance of Wei-Jen Chang, Ju-Huei Liu, Z.-W. Jessica Huang, Yu-Jer Shie, Pei-Ling Lin, Yi-Hung Lin, and Ying-Hong Lin are also acknowledged.

\section{References}

[1] S. Lindquist, E.A. Craig, The heat-shock proteins, Ann. Rev. Genet. 22 (1988) 631-677.
[2] D.A. Parsell, S. Lindquist, The function of heat-shock proteins in stress tolerance: degradation and reactivation of damaged proteins, Ann. Rev. Genet. 27 (1993) 437-496.

[3] E. Vierling, The roles of heat shock proteins in plants, Ann. Rev. Plant Pyhsiol. Plant Mol. Biol. 42 (1991) 579-620.

[4] M.A. Mansfield, J.L. Key, Synthesis of low molecular weight heat shock proteins in plants, Plant Physiol. 84 (1987) 1007-1017.

[5] P.R. LaFayette, R.T. Nagao, K. O’Grady, E. Vierling, J.L. Key, Molecular characterization of cDNAs encoding low-molecular-weight heat shock proteins of soybean, Plant Mol. Biol. 30 (1996) 159-169.

[6] E.R. Waters, G.J. Lee, E. Vierling, Evolution, structure and function of the small heat shock proteins in plants, J. Exp. Bot. 47 (1996) 325-338.

[7] K.D. Scharf, M. Siddique, E. Vierling, The expanding family of Arabidopsis thaliana small heat stress proteins and a new family of proteins containg $\alpha$-crystalline domains (Acd proteins), Cell Stress Chaperones 6 (2001) 225-237.

[8] T.L. Jinn, S.H. Wu, C.H. Yeh, M.H. Hsieh, Y.C. Yeh, Y.M. Chen, C.Y. Lin, Immunological kinship of class I low molecular weight heat shock proteins and thermostabilization of soluble proteins in vitro among plants, Plant Cell Physiol. 34 (1993) 1055-1062.

[9] T.L. Jinn, Y.M. Chen, C.Y. Lin, Characterization and physiological function of class I small heat-shock protein complex in soybean, Plant Physiol. 108 (1995) 693-701.

[10] C.H. Yeh, K.W. Yeh, S.H. Wu, P.F.L. Chang, Y.M. Chen, C.Y. Lin, A recombinant rice $16.9 \mathrm{kDa}$ heat shock protein can provide thermotolerance in vitro, Plant Cell Physiol. 36 (1995) 1341-1348.

[11] C.H. Yeh, P.F.L. Chang, K.W. Yeh, W.C. Lin, Y.M. Chen, C.Y. Lin, Expression of a gene encoding a 16.9 kDa heat-shock protein, Oshsp16.9, in Escherichia coli enhances thermotolerance, Proc. Natl. Acad. Sci. USA 94 (1997) 10967-10972.

[12] C.H. Yeh, Y.M. Chen, C.Y. Lin, Functional regions of rice heat shock protein, Oshsp16.9, required for conferring thermotolerance in Escherichia coli, Plant Physiol. 128 (2002) 661-668.

[13] L.S. Young, C.H. Yeh, Y.M. Chen, C.Y. Lin, Molecular characterization of Oryza sativa 16.9 kDa heat shock protein, Biochem. J. 344 (1999) 31-38.

[14] P.F.L. Chang, C.Y. Huang, F.C. Chang, T.S. Tseng, W.C. Lin, C.Y. Lin, Isolation and characterization of the third gene encoding a $16.9 \mathrm{kDa}$ class I small heat shock protein, Oshsp16.9C, in rice, Bot. Bull. Acad. Sinica 42 (2001) 85-92.

[15] J.C. Guan, T.L. Jinnt, C.H. Yeh, S.P. Feng, Y.M. Chen, C.Y. Lin, Characterization of the genomic structures and selective expressions of nine class I small heat shock protein genes clustered on two chromosomes in rice (Oryza sativa L.), Plant Mol. Biol. 56 (2004) 795-809.

[16] Y.L. Lee, P.F.L. Chang, K.W. Yeh, T.L. Jinn, C.C.S. Kung, W.C. Lin, Y.M. Chen, C.Y. Lin, Cloning and characterization of a cDNA encoding an 18.0-kDa class I low-molecular-weight heat shock protein from rice, Gene 165 (1995) 223-227.

[17] T.S. Tseng, S.S. Tzeng, K.W. Yeh, C.H. Yeh, F.C. Chang, Y.M. Chen, C.Y. Lin, The heat-shock response in rice seedlings: isolation and expression of cDNAs that encode class I low-molecular-weight heat-shock-proteins, Plant Cell Physiol. 34 (1993) 165-168.

[18] S.S. Tzeng, Y.M. Chen, C.Y. Lin, Isolation and characterization of genes encoding $16.9 \mathrm{kD}$ heat shock proteins in Oryza sativa, Bot. Bull. Acad. Sinica 34 (1993) 133-142.

[19] B.G. Atkinson, M. Raizada, R.A. Bouchard, J.R.H. Frappier, D.B. Walden, The independent stage-specific expression of the $18 \mathrm{kDa}$ heat shock protein genes during microsporogenesis in Zea mays L., Dev. Genet. 14 (1993) 15-26.

[20] M.A. Coca, C. Almoguera, J. Jordano, Expression of sunflower lowmolecular-weight heat-shock proteins during embryogenesis and persistence after germination: localization and possible functional implications, Plant Mol. Biol. 25 (1994) 479-492.

[21] P.S. Dietrich, R.A. Bouchard, E.S. Casey, R.M. Sinibaldi, Isolation and characterization of a small heat shock protein gene from maize, Plant Physiol. 96 (1991) 1268-1276.

[22] P. Krishna, R.F. Felsheim, J.C. Larkin, A. Das, Structure and light-induced expression of a small heat-shock protein gene of Pharbitis nil, Plant Physiol. 100 (1992) 1772-1779. 
[23] D. Bartling, H. Bulter, K. Liebeton, E.W. Weiler, An Arabidopsis thaliana cDNA clone encoding a $17.6 \mathrm{kDa}$ class II heat shock protein, Plant Mol. Biol. 18 (1992) 1007-1008.

[24] L.M. Lauzon, K.W. Helm, E. Vierling, A cDNA clone from Pisum sativum encoding a low molecular weight heat shock protein, Nucleic Acids Res. 18 (1990) 4274.

[25] C.K. Ding, C.Y. Wang, K.C. Gross, D.L. Smith, Reduction of chilling injury and transcript accumulation of heat shock proteins in tomato fruit by methyl jasmonate and methyl salicylate, Plant Sci. 161 (2001) 11531159.

[26] C. Almoguera, M.A. Coca, J. Jordano, Tissue-specific expression of sunflower heat shock proteins in response to water stress, Plant J. 4 (1993) 947-958.

[27] Y.H. Cheong, H.S. Chang, R. Gupta, X. Wang, T. Zhu, S. Luan, Transcriptional profiling reveals novel interactions between wounding, pathogen, abiotic stress, and hormonal responses in arabidopsis, Plant Physiol. 129 (2002) 661-677.

[28] S.M. Clarke, L.A. Mur, J.E. Wood, I.M. Scott, Salicylic acid dependent signaling promotes basal thermotolerance but is not essential for acquired thermotolerance in Arabidopsis thaliana, Plant J. 38 (2004) 432-447.

[29] M.J. Cronje, L. Bornman, Salicylic acid influences Hsp70/Hsc70 expression in Lycopersicon esculentum: dose- and time-dependent induction or potentiation, Biochem. Biophys. Res. Commun. 265 (1999) 422427.

[30] P.F.L. Chang, K.T. Cheah, M.L. Narasimhan, P.M. Hasegawa, R.A. Bressan, Osmotin gene expression is controlled by elicitor synergism, Physiol. Plant. 95 (1995) 620-626.

[31] P.F.L. Chang, M.L. Narasimhan, P.M. Hasegawa, R.A. Bressan, Quantitative mRNA-PCR for expression analysis of low-abundance transcripts, Plant Mol. Biol. Reporter 11 (1993) 237-248.

[32] P.F.L. Chang, B. Damsz, A.K. Kononowicz, M. Reuveni, Z. Chen, Y. Xu, K. Hedges, C.C. Tseng, N.K. Singh, M.L. Binzel, M.L. Narasimhan, P.M. Hasegawa, R.A. Bressan, Alterations in cell membrane structure and expression of a membrane-associated protein after adaptation to osmotic stress, Physiol. Plant. 98 (1996) 505-516.

[33] M. Zuker, Mfold web server for nucleic acid folding and hybridization prediction, Nucleic Acids Res. 31 (2003) 3406-3415.

[34] D.H. Mathews, J. Sabina, M. Zuker, D.H. Turner, Expanded sequence dependence of thermodynamic parameters improves prediction of RNA secondary structure, J. Mol. Biol. 288 (1999) 911-940.

[35] J.D. Thompson, D.G. Higgins, T.J. Gibson, CLUSTAL W: improving the sensitivity of progressive multiple sequence alignment through sequence weighting, position-specific gap penalties and weight matrix choice, Nucleic Acids Res. 22 (1994) 4673-4680.

[36] J.D. Thompson, T.J. Gibson, F. Plewniak, F. Jeanmougin, D.G. Higgins, The CLUSTAL $\mathrm{X}$ windows interface: flexible strategies for multiple sequence alignment aided by quality analysis tools, Nucleic Acids Res. 25 (1997) 4876-4882.
[37] D.S. Swofford, PAUP*: Phylogenetic Analysis using Pasimony $\left(^{*}\right.$ and other methods). Version 4, Sinauer Associates, Sunderland, MA, 2000.

[38] T.L. Jinn, P.F.L. Chang, Y.M. Chen, J.L. Key, C.Y. Lin, Tissue typespecific heat shock response and immunolocalization of class I low molecular weight heat shock proteins in soybean, Plant Physiol. 114 (1997) 429-438.

[39] J. Weng, Z.F. Wang, H.T. Nguyen, A Triticum aestivum cDNA clone encoding a low-molecular-weight heat shock protein, Plant Mol. Biol. 17 (1991) 273-275.

[40] T. Sasaki, T. Matsumoto, K. Yamamoto, K. Sakata, T. Baba, Y. Katayose, J. Wu, Y. Niimura, Z. Cheng, Y. Nagamura, B.A. Antonio, H. Kanamori, S. Hosokawa, M. Masukawa, K. Arikawa, Y. Chiden, M. Hayashi, M. Okamoto, T. Ando, H. Aoki, K. Arita, M. Hamada, C. Harada, S. Hijishita, M. Honda, Y. Ichikawa, A. Idonuma, M. Iijima, M. Ikeda, M. Ikeno, S. Ito, T. Ito, Y. Ito, Y. Ito, A. Iwabuchi, K. Kamiya, W. Karasawa, S. Katagiri, A. Kikuta, N. Kobayashi, I. Kono, K. Machita, T. Maehara, H. Mizuno, T. Mizubayashi, Y. Mukai, H. Nagasaki, M. Nakashima, Y. Nakama, Y. Nakamichi, M. Nakamura, N. Namiki, M. Negishi, I. Ohta, N. Ono, S. Saji, K. Sakai, M. Shibata, T. Shimokawa, A. Shomura, J. Song, Y. Takazaki, K. Terasawa, K. Tsuji, K. Waki, H. Yamagata, H. Yamane, S. Yoshiki, R. Yoshihara, K. Yukawa, H. Zhong, H. Iwama, T. Endo, H. Ito, J.H. Hahn, H.I. Kim, M.Y. Eun, M. Yano, J. Jiang, T. Gojobori, The genome sequence and structure of rice chromosome 1, Nature 420 (2002) 312-316.

[41] The Rice Full-Length cDNA Consortium, Collection, mapping, and annotation of over 28,000 cDNA clones from japonica rice, Science 301 (2003) 376-379.

[42] W. Wang, B. Vinocur, O. Shoseyov, A. Altman, Role of plant heat-shock proteins and molecular chaperones in the abiotic stress response, Trends Plant Sci. 9 (2004) 244-252.

[43] Z. Vaghchhipawala, R. Bassuner, K. Clayton, K. Lewers, R. Shoemaker, S. Mackenzie, Modulations in gene expression and mapping of genes associated with cyst nematode infection of soybean, Mol. Plant Microbe Interact. 14 (2001) 42-54.

[44] A. Takahashi, C. Casais, K. Ichimura, K. Shirasu, HSP90 interacts with RAR1 and SGT1 and is essential for RPS2-mediated disease resistance in Arabidopsis, Proc. Natl. Acad. Sci. USA 100 (2003) 11777-11782.

[45] D.A. Hubert, P. Tornero, Y. Belkhadir, P. Krishna, A. Takahashi, K. Shirasu, J.L. Dangl, Cytosolic HSP90 associates with and modulates the Arabidopsis RPM1 disease resistance protein, EMBO J. 22 (2003) 5679-5689.

[46] H. Kanzaki, H. Saitoh, A. Ito, S. Fujisawa, S. Kamoun, S. Katou, H. Yoshioka, R. Terauchi, Cytosolic HSP90 and HSP70 are essential components of INF1-mediated hypersensitive response and non-host resistance to Pseudomonas cichorii in Nicotiana benthamiana, Mol. Plant Pathol. 4 (2003) 383-391.

[47] J.R. Frappier, D.B. Walden, B.G. Atkinson, Translation of some maize small heat shock proteins is initiated from internal in-frame AUGs, Genetics 148 (1998) 471-477. 